\title{
Monitoring and Evaluation of the Agricultural and Rural Renewal Program in Algeria: case of the Ouarsenis area ${ }^{1}$
}

\author{
Mohamed Tebani ${ }^{2}$ and Khalladi Mederbal ${ }^{3}$
}

\begin{abstract}
In Algeria, agriculture continues to suffer from short-term strategies and is unsuitable for the needs of populations and rural areas. This study examines the evaluation of the Agricultural and Rural Program (ARRP) initiated in Algeria for the period (20092014). This work was carried in the Ouarsenis area located in the north-west of the country. It is based on regular monitoring on the ground of the rate of achievement of the targets foreseen. We concentrated our efforts on the projects financed by the main intervention funds of this program. The results achieved are far from the targets for the economic component, a situation mainly expressed by the low income of the rural population and the number of jobs created. However, an improvement in the living conditions of the population was recorded in the social component. Concerning the environmental aspect, the results are considered acceptable for the restoration of the forest patrimony and low for the protection of the soil. We believe that this policy rests on foundations that have not really been translated into the field in the continuity of previous approaches and lack of governance with poorly managed material, financial and human resources.
\end{abstract}

Key-words: Agricultural policies, agricultural economy, rural development, Ouarsenis, Algeria.

Resumen: En Argelia, la agricultura sigue sufriendo de estrategias a corto plazo y no es adecuada para las necesidades de las poblaciones y las zonas rurales. Este estudio examina la evaluación del Programa de Renovación Agrícola y Rural (Prar) iniciado en Argelia para el período (2009-2014). Este trabajo se realizó en el área de Ouarsenis ubicada en el Noroeste del país, se basa en el monitoreo regular sobre la base de la tasa de logro de los objetivos previstos. Hemos concentrado nuestros esfuerzos en los proyectos financiados por las principales herramientas de intervención de este programa, a saber, el Fondo Nacional de Desarrollo de la Inversión Agrícola (FNDIA) y el Fondo de Desarrollo Rural y Valorización de la Tierra por Concesión (FDRVTC). Los resultados obtenidos están lejos de los objetivos para el componente económico, una situación expresada principalmente por los bajos ingresos de la población rural y la cantidad de empleos creados. Sin embargo, se registró

1. Submitted on September, 13, 2017. Accepted on February, 26, 2018.

2. University Mustapha Stambouli of Mascara, Faculty of Nature and Life Sciences, 29000 Mascara, Algeria. E-mail: mail: mohamedtebani.e@gmail.com

3. University Ibn Khaldoun of Tiaret, 14000 Tiaret, Algeria. E-mail: kmedrbal@yahoo.fr 
una mejora en las condiciones de vida de la población para el componente social. En cuanto al aspecto ambiental, los resultados se consideran aceptables para la restauración del patrimonio forestal y bajos para la protección del suelo. Creemos que esta política se basa en fundaciones que no han sido realmente traducidas en el terreno en la continuidad de los enfoques anteriores y una falta de gobernabilidad con recursos materiales, financieros y humanos mal gestionados.

Palabras clave: Las políticas agrícolas, economía agrícola, el desarrollo rural, Ouarsenis, Argelia.

JEL classification: Q14, Q18, R42, R58.

DOI: http://dx.doi.org/10.1590/1234-56781806-94790560410

\section{Introduction}

Since independence, Algerian agriculture has had short-term strategies that have not solved the problems of the sector (AKERKAR, 2015), which has resulted in an imbalance between rural and urban areas (SOUIDI and BESSAOUD, 2011). The sector contribution of agriculture to the gross domestic product (GDP) is only $9 \%$ and only $25 \%$ employment for $42 \%$ of the total labor force (BEDRANI, 2008). This precarious situation is the result of a lack of concordance of agricultural policies with the socio-economic structure of the rural world, from the self-management of farms (1962-1971) by former colonial agricultural workers to safeguard the productive heritage (HERSI, 1981) and then the land revolution (1971-1979) by land redistribution to landless peasants and the reorganization of land management and exploitation (BESSAOUD, 1980), followed by the first land reforms known as the restructuration of the agricultural socialist domains (ASD), (BOUAMMAR, 2010), up to the period (1987-2000), with the abandonment of subsidies and the transformation of the ASD into collective and individual agricultural holdings (1979-1987), (MARD, 2012). Another strategy was adopted between 2000 and 2008, namely the National Plan for Agricultural and Rural Development (NPARD), a substantial budget of 350 billion Algerian dinar (DZD) was committed and DZD 14 billion of the debts were erased for the farmers, but the export of agricultural products increased by less than $\$ 3$ billion in 2003, \$ 8 billion in 2008 and \$ 11 billion in
2011 (MARD, 2012). In our study area "El'Ouarsenis" DZD 1.46 billion were invested during the period (2000-2005) in the form of a subsidy granted by the National Regulatory and Agricultural Development Fund (NRADF) to the benefit of 1115 farms, but the success rate did not exceed 20\% (TEBANI, 2008). None of these reforms have met the objectives assigned to them and the recommended development model remains unsuitable for the needs of populations and rural areas (NCSAPD, 2002).

Given this situation, the Agricultural and Rural Renewal Program (ARRP) launched by MARD in 2008 adopted a new vision of the rural world through other methods of intervention based on the participation of project leaders and adaptation of projects to local specificities. First of all, it was necessary to clear DZD 41 billion of debts to the farmers and to mobilize DZD 200 billion for the period (2009 - 2014) to infuse new dynamics with the agricultural growth and the sustainable development of the rural territories (MARD, 2009). The fundamental objective of the new strategy is the national food security and revitalization of rural areas (MAGHNI, 2013). The action plan for this strategy is based on three strands of integrated logic:

1. The agricultural renewal program (ARP), based on the economic dimension and the profitability of the sector, aims at increasing and modernizing agricultural production,

2. The Rural Renewal Program (RRP), for the balanced and sustainable development of rural areas, namely environmental and socioeconomic actions, 
3. The Human Capacity Building and Technical Assistance program (HCBTAP) is a crosscutting objective aimed at strengthening the technical supervision of local government and the means of monitoring and controlling programs.

This approach relies on a potential oriented towards the mobilization of men and their capacities, the valorization of the natural, patrimonial and economic wealth of their territories (FERROUKHI, 2009).

To achieve this strategy, performance contracts for the 2009-2014 period are signed between MARD on the one hand and the Wilayas (districts) represented by the agricultural services directorates for the agricultural renewal (AR) and the forest conservators for the rural renewal (RR). On the other hand, these contracts represent an effective means of ensuring better monitoring and evaluation of the implementation of these state-supported programs. However, in the absence of a tradition of evaluating public policies in Algeria, the management authorities merely establish physical and financial assessments instead of an actual evaluation (AKERKAR, 2015).

Our study consists of measuring the results of this program to see if this strategy has a real impact on agricultural production and improvement of the population's standard of living and whether it is a policy that differs from previous policies.

The aim of our work is to evaluate the success rate of the program in the Ouarsenis area as a region representative of mountain agriculture for several regions of Algeria and to provide recommendations that can be exploited by the parties concerned with the sustainable development of rural areas.

\section{The study area}

Our study area "El Ouarsenis " is located in the north of the wilaya of Tissemsilt in the northwest of Algeria; it is represented by seven communes (municipalities), as Figure 1 indicates.

It is a silvo-agricultural zone, with an area of 57000 ha. It is characterized by a rugged mountainous terrain with steep slopes, $76.9 \%$ of the surface at altitudes ranging from 650 to 1100 meters, with poorly developed raw mineral soils and isohumic soils disposed to erosion. The bioclimatic stage of the region is sub humid with low precipitation (419 $\mathrm{mm} /$ year) and temperature varies between $38 \mathrm{C}^{\circ}$ in Summer and $4 \mathrm{C}^{\circ}$ in Winter. The forest area occupies $40.35 \%$ of the total area and is represented by Aleppo pine and green oak. The area has 56,983 inhabitants (General Census of Population and Habitat (GCPH, 2008), 57\% of whom

Figure 1. Location of the area study

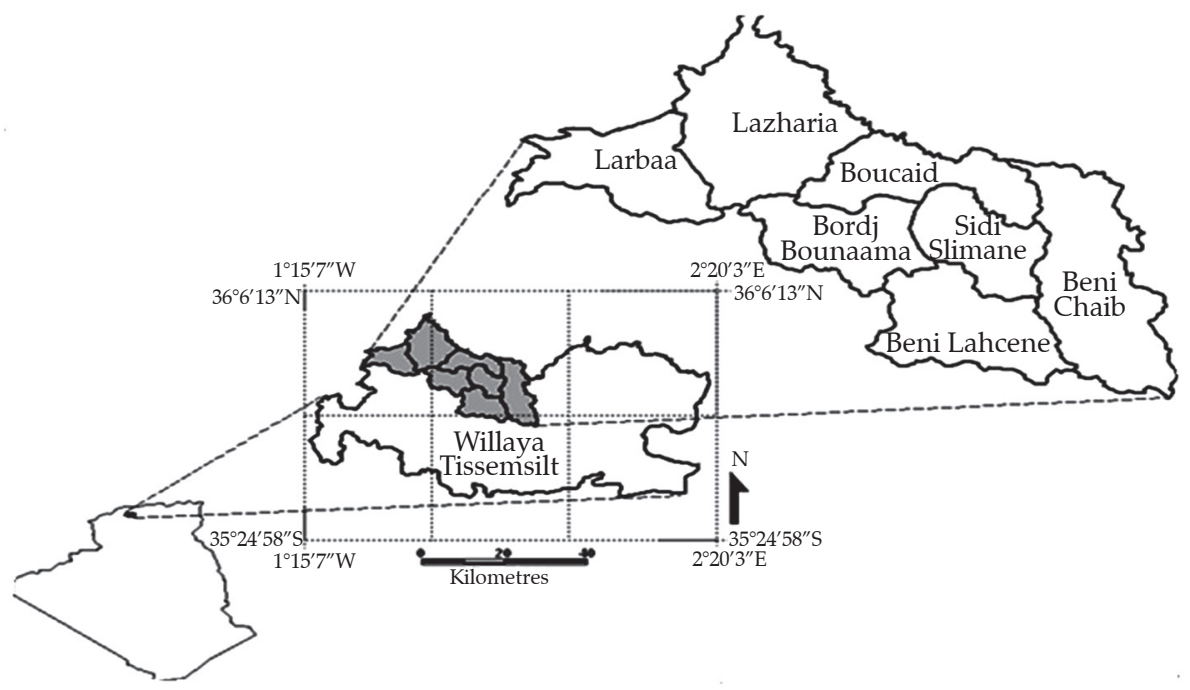

Source: Created by the author. 
live in rural areas, and $64 \%$ are between 19 and 60 years of age. The illiteracy rate is $53 \%$. The employment rate is $26.73 \%$ of the total active population, the agriculture sector employs $29 \%$ of the employed, construction $27 \%$, services $21 \%$, administration $20 \%$ and industrial sector occupies only $2 \%$. Female employment does not exceed $4 \%$ and is mainly represented by the administration at the chief places of the communes.

\section{Methodology}

Our efforts were concentrated on the monitoring and evaluation of the physical implementation rate of the ARRP projects and the results were compared with the objective referred. The growth rate for each action carried out was estimated subsequently. The program was followed gradually during the course of its operations throughout the period considered. After the program closure we adopted a retrospective evaluation which can be useful for prospective analysis for the programs of the next strategy. To carry out this work well, we have concentrated our efforts on the follow-up of the actions subsidized by the two main intervention tools of this strategy (Figure 2).
1. Agricultural Investment Projects (AIP) registered and committed by individual farmers and partially subsidized through the National Agricultural Investment Development Fund (NAIDF) for Agricultural Renewal (AR).

2. Integrated Rural Development Proximity Projects (IRDPP) for socio-economic and environmental interest, individually or collectively, financed wholly or partly by the Rural Development and Concession Land Development Fund (RDCLDF) for the Rural Renewal (RR).

More than these funds, we took into account the quantities of agricultural production realized on selffinancing of the farmers thatare estimated on the ground through periodic visits. Outputs were analyzed according to the three strands of sustainability economic, environmental and social.

The evaluation of HCBTAP (transversal axis) concerns the monitoring of the number of farmers who have benefited from one or more extension and / or training sessions in the various agricultural sectors and the number of PRAR follow-up officers who received advanced training for agricultural and forestry services.

Figure 2. The monitoring and evaluation matrix of the Agricultural and Rural Renewal Program at the local level (Ouarsenis)

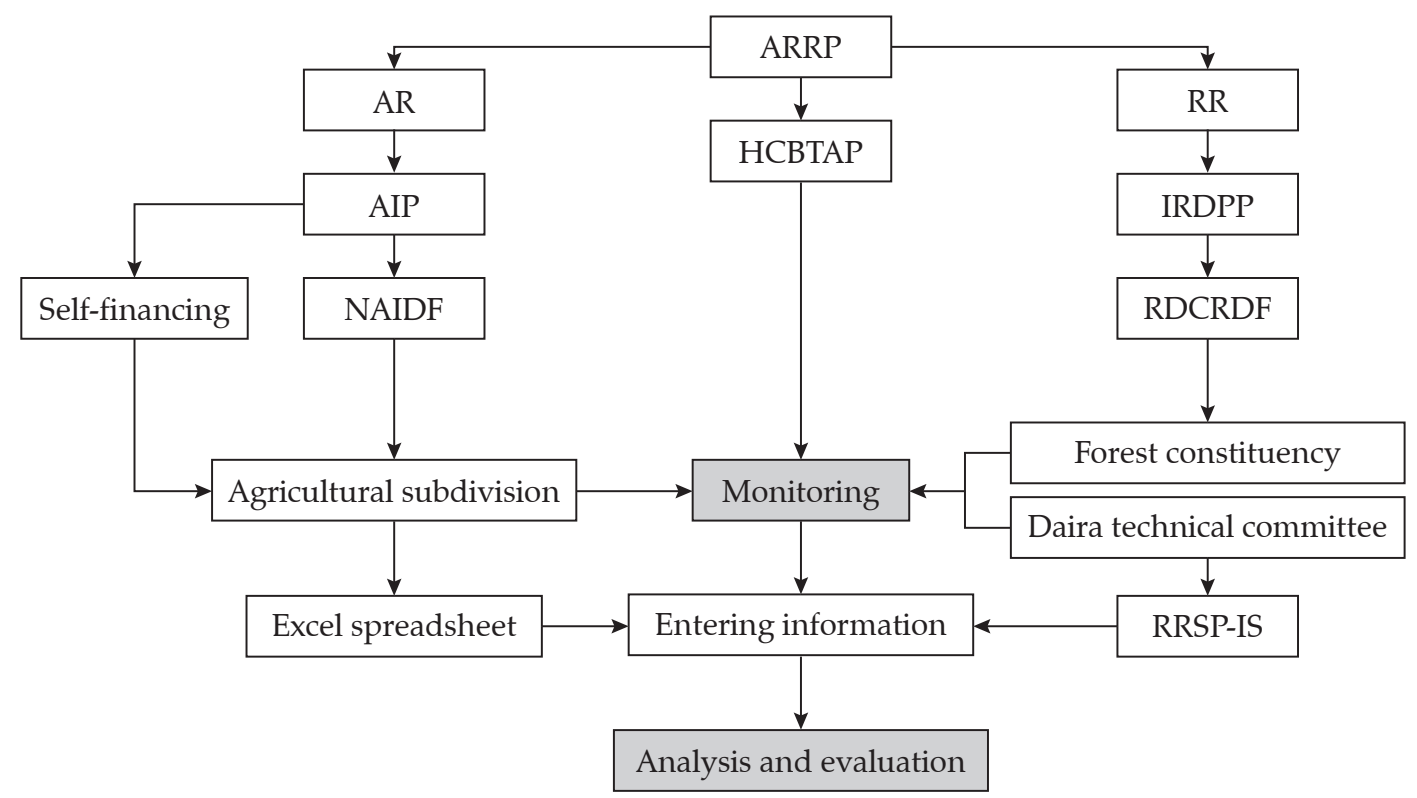

Source: Elaborated by authors. 
Evaluation may be endogenous (by elected officials, government officials) as it may be exogenous (by a third party) and may also be mixed (participatory) between internal parties and external parties (ZAGHIB, 2009). Follow-up was done by us as head of the agricultural sub-division for agricultural investment projects (AIP) and as the facilitator of the Daira technical committee for the integrated proximity program for rural development (IPPRD). In the case of investment agricultural projects (IAP), information was captured using an Excel spreadsheet and IPPRD using a Rural Renewal Support Program Information System (RRSP- IS); monthly and annual reports have been prepared and the final results obtained have been analyzed and evaluated.

\section{Results and discussion}

The results of monitoring the actions carried out are analyzed along the economic, environmental and social axes.

\subsection{The economic aspect}

This is the most important aspect to analyze and concerns mainly agricultural production (plant and animal).

\subsubsection{Vegetable production}

The monitoring of the area planted has allowed us to have the results of the corresponding production for the various sectors.

Production levels showed a small increase compared to the targets. In terms of area, $36 \%$ of the target was planted and reached a growth of $15 \%$, or $18601 \mathrm{ha}$, but the irrigated area does not exceed $8 \%$. The low yield is due mainly to adverse climatic conditions, insufficient irrigation water, choice of unsuitable species and traditional cultural techniques.

Concerning olive cultivation supported in the program by plants and soil works, the planted area reaches $33 \%$ of the planned objectives and results in an aggregate of $3524 \mathrm{ha}$, of which $42 \%$ productive. The yield is not more than 7quintals/ ha (compared to 23qq / ha at the national average) for this much dispersed area of poorly maintained old trees or young dry plantations of low production. The large part is destined for the production of olive oil in a traditional way for this strategic sector in the region.

For arboriculture, $28 \%$ of the target was achieved and results in an area of 2459 ha in 2014. The subsidy concerns rustic species (almond and fig tree). The yield remains insufficient and depends on each species with a mean of $35 \mathrm{qq} /$ ha; however the production is of good biological quality where the use of fertilizers and pesticides has been avoided.

For annual crops, the objective of the production achieved reaches an average level with such low yields due to the non-completion of the irrigation projects supported by the state. Vegetable crops have been intensified, inter alia, by irrigated tree orchards. $28 \%$ of the assigned objectives were achieved and resulted in an area of 391 ha. This state is contributing to a significant increase in production mainly for self-consumption.

The area of dried pulses was only evolved with $10 \%$ or 323 aa. The objective of extending this state through the use of fallow land and the conversion of some cereal areas has not even been achieved with the awareness of farmers adapted to the traditional monoculture.

Cereal cultivation remains the most dominant speculation in the region in terms of area with $61 \%$

Table 1. Evolution of crop production

\begin{tabular}{lccccc}
\hline \multirow{2}{*}{$\begin{array}{c}\text { Vegetable production } \\
(\mathbf{Q q})\end{array}$} & $\begin{array}{c}\text { Initial state } \\
\text { Year 2008 }\end{array}$ & \multicolumn{2}{c}{ Final State Year 2014 } & Rate of achievement & $\begin{array}{c}\text { Rate of growth } \\
(\mathbf{\%})\end{array}$ \\
\hline Olive growing & 4270 & Target & Realization & & (\%) \\
Arboriculture & 68250 & 17550 & 5992 & 13 & 40 \\
Market gardening & 21280 & 131250 & 86065 & 28 & 26 \\
Dried vegetables & 15000 & 36990 & 26050 & 30 & 22 \\
Cereal & 101660 & 18300 & 16600 & 48 & 11 \\
Feed & 3360 & 114410 & 116592 & 117 & 15 \\
\hline
\end{tabular}

Source: Prepared by the authors. 
of the total planted or 11370 ha after its extension by $7 \%$ in the improved land. The average yield does not exceed $11 \mathrm{qq} / \mathrm{ha}$ in the best seasons of precipitation. The output of the year 2014 observed exceeds the objective; it is justified by the excess of the estimates to be emblazoned. BeniChaib is the only cerealbased commune that will have to support irrigation through the Kodiet-Rosfa dam; the others are of minor importance with small plots that will have to be converted by other profitable crops such as olive and pulses.

The area of fodder crops remains insufficient for the existing livestock even with its extension reaching 525 ha. The situation will need to be redressed by increasing the area planted and irrigated to reduce free grazing and its consequences on environmental degradation and forest cover.

\subsubsection{Animal production}

A remarkable evolution of production was observed from one commune to another. The results achieved are presented in order of priority to the area in Table 2.

In terms of honey production, $32 \%$ of the target for the acquisition of hives was reached, or 3470 full hives, resulting in a significant increase with $34 \%$, or a state of 13670 hives in 2014. The production of Honey estimated on land does not correspond to this evolution and remains far from the target. The 8305 hives remain productive, yielding an average yield of no more than $5 \mathrm{~kg} /$ hive in this hilly region. This low rate is due to lack of control over beekeeping techniques under cold winter conditions.

For white meat, the target achieved reaches $70 \%$ of the poultry farms added, or 53 units. The 147 operational parks participate with an improvement of production of the white meat by $52 \%$ in favor of the local market and even in the neighboring regions. High food prices and traditional practices are the main reasons for the low rate.

The improvement observed in the production of red meat and milk is due to the increase of the bovine, sheep and goat population to $15 \%, 16 \%$ and $15 \%$ after completion of $36 \%, 55 \%$ and $55 \%$ of the targets, or 1735 heads, 11597 heads 16120 heads. This new situation contributed to the growth of red meat production with $19 \%$ (36\% beef, 33\% sheep and 31\% goat). Milk production increased with 19\% (goats produce $60 \%$, ewes $22 \%$ and dairy cows $18 \%$ ). This state is far from self-sufficiency with predominantly low-performing local breeds. The main constraints remain the high price of forage and the area of very low free grazing.

\subsection{Actions of environmental interest}

In order to restore the natural heritage, the actions followed are summarized in two parts:

\subsubsection{Management and protection of the forest heritage}

Are the silvicultural works of ecological and economic interest for this heritage. $85 \%$ of the estimated objective was achieved for reforestation and forest restoration based on Aleppo pine and $73 \%$ for pruning and clearing of forests. This work was carried out mainly in 2010 and 2011 after the large areas recorded fires. The continued degradation of this forest ecosystem requires more effort for its management within a framework of sustainable development in order to play its role in ecotourism, timber production and erosion control.

Table 2. Evolution of livestock production

\begin{tabular}{|c|c|c|c|c|c|}
\hline \multirow{2}{*}{ Animal production } & \multirow{2}{*}{$\begin{array}{l}\text { Initial state } \\
\text { Year } 2008\end{array}$} & \multicolumn{2}{|c|}{ Final State Year 2014} & \multirow{2}{*}{$\begin{array}{c}\text { Rate of achievement } \\
(\%)\end{array}$} & \multirow{2}{*}{$\begin{array}{c}\text { Rate of growth } \\
(\%)\end{array}$} \\
\hline & & Target & Realization & & \\
\hline Production of honey (Qq) & 327 & 823 & 415 & 18 & 27 \\
\hline Production of white meat (Qq) & 5640 & 11400 & 8580 & 51 & 52 \\
\hline Red meat production $(\mathrm{Qq})$ & 2770 & 3883 & 3302 & 48 & 19 \\
\hline Milk production (HL) & 2561 & 3405 & 3046 & 57 & 19 \\
\hline
\end{tabular}

Source: Prepared by the authors. 
Table 3. Follow-up of the actions of the forest improvement and the protection of watersheds

\begin{tabular}{l|cc|cccc}
\hline & \multicolumn{2}{|c|}{$\begin{array}{c}\text { Management and protection } \\
\text { of forest heritage }\end{array}$} & \multicolumn{3}{c}{ Watershed protection } \\
\cline { 2 - 7 } & $\begin{array}{c}\text { Reforestation } \\
\text { and forest } \\
\text { restocking } \\
(\mathrm{Ha})\end{array}$ & $\begin{array}{c}\text { Forest cleansing } \\
\text { and pruning }\end{array}$ & $\begin{array}{c}\text { Torrential } \\
\text { correction - } \\
\text { mechanical } \\
\left(\mathrm{m}^{3}\right)\end{array}$ & $\begin{array}{c}\text { Torrential } \\
\text { correction - } \\
\text { Biological } \\
(\mathrm{Ha})\end{array}$ & $\begin{array}{c}\text { Construction } \\
\text { and repair of } \\
\text { benches } \\
(\mathrm{Ha})\end{array}$ & $\begin{array}{c}\text { Land } \\
\text { improvement } \\
(\text { Ha) }\end{array}$ \\
\hline Target & 2975 & 3130 & 25600 & 241 & 732 & 970 \\
Realization & 2530 & 2287 & 9240 & 40 & 165 & 225 \\
Rate of achievement $(\%)$ & 85 & 73 & 36 & 16 & 22 & 23 \\
\hline
\end{tabular}

Source: Prepared by the authors.

\subsubsection{Watershed protection}

The level of achievement remains low for all operations undertaken in this framework (Table 3). Concerning the torrential correction, the mechanical work (with dry stone) coincides with the difficulty of access to the land of steep slopes and sensitive to water erosion, the biological type (bank fixation) concentrated at the borders of the rivers and the roads to protect the soil that has experienced a low success rate due poorly selected and maintained species. For banquettes that have an importance to the restoration of the soil and the economic development, this low result is due to the exodus of the population of the zones concerned and the conflict for the collective management of this type of projects. Land improvement is still difficult to achieve in this region with small private plots.

\subsection{Actions with a social interest}

For the social aspect, we tried to analyze the consequences for individuals, the main parameters relate to employment and living conditions.

Figure 3. Evolution empoyment in Ouarsenis area (2009-2014)

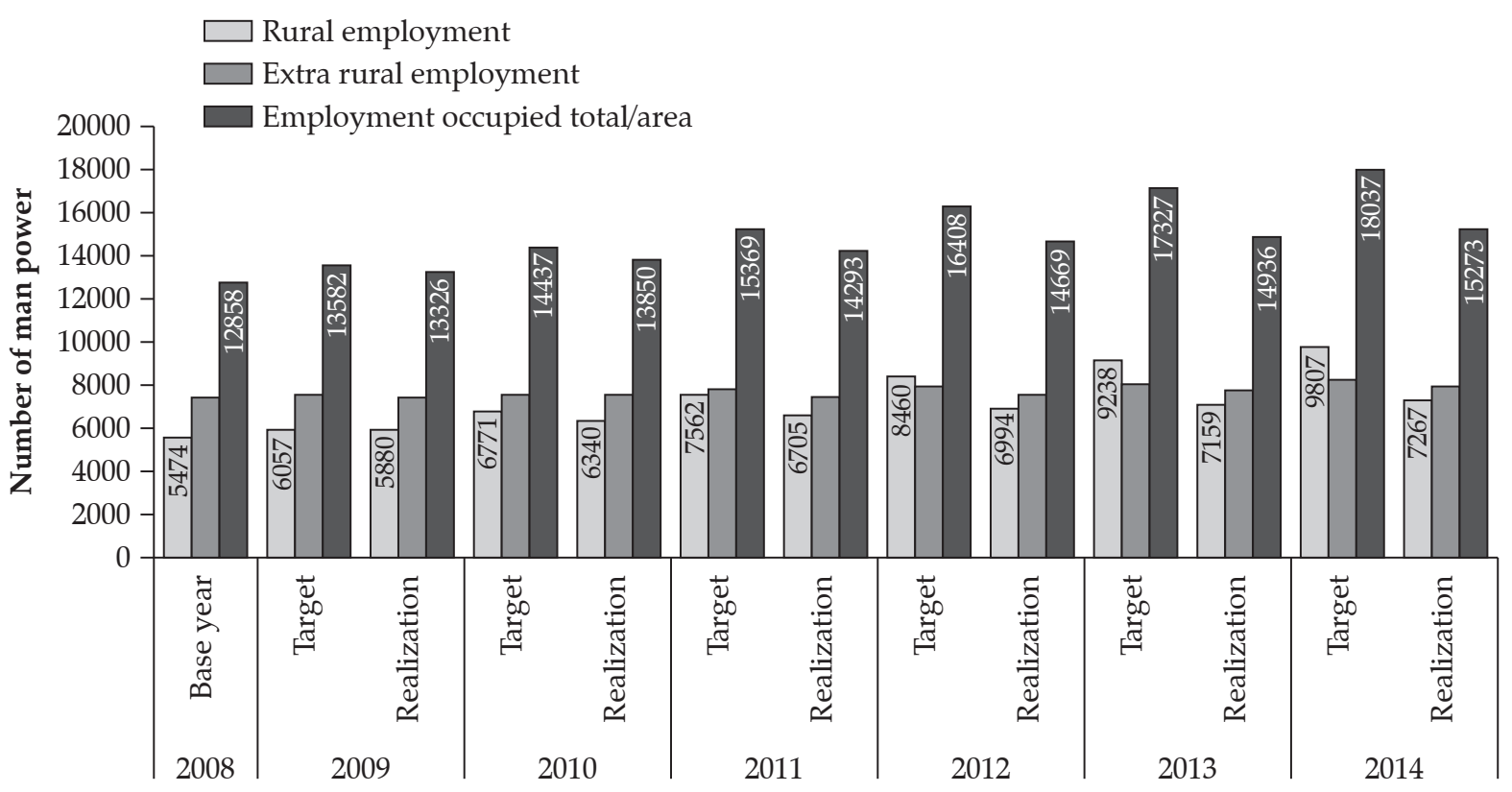

Source: Elaborated by authors. 


\subsubsection{Evolution of Employment}

Rural employment was analyzedbased on agricultural and other activities created at the level of rural work sites. Agricultural employment has evolved from $32 \%$ for permanent workers to $29 \%$ for seasonal workers. The result of the total rural employment equivalent has been improved with $32 \%$. Given the rural-urban interconnection, a significant number of rural areas remain dependent on non - rural employment from urban areas, such as construction, services and administration. The new total employment situation contributed to the reduction of the unemployment rate by $7 \%$ in rural areas and $5 \%$ in the area. The employment rate Feminine represents $12 \%$ in the rural environment, particularly crafts and small livestock and $11 \%$ in the urban environment, especially in the administration.

Overall, the employment trend recorded during the period (2009-2014) remains insignificant in view of the growth of the rural labor force estimated at $4.65 \%$ (5.15\% for the total of Ouarsenis) even the number of farms increased by $3.77 \%$ acceding 2040 to 2120 , but they are mostly small $(49 \%$ with an area of less than $5 \mathrm{ha}$ ), which is created as a single unit occupied by a single employment post, with low returns and unable to produce the minimum necessary for the maintenance of families; agriculture remains a secondary and seasonal activity for a large part of the agricultural population.

From an organizational point of view, the rural employment situation in Ouarsenis is like the majority of Algerian regions characterized by the low qualifications of the employees, the lack of a change of farmers in old age, poor integration conditions of agricultural institutions and organizations $(20 \%$ adhering to the Chamber of Agriculture, 6\% insurance, $4 \%$ to the agricultural bank and represented only by 4 associations of low activity).

\subsubsection{Improvement of living conditions}

Efforts in this area have resulted in improvements in basic infrastructure and equipment. One state was observed by the opening up of the 57 agglomerations dispersed in the zone resulting from the improvement of the rural tracks over $648 \mathrm{~km}$. The rural housing stock has been widely expanded and modernized with the help of the self-construction of 1661 dwellings, resulting in an occupancy rate per dwelling (ORD) 6.55 instead of 7.50 in 2008. These dwellings have been upgraded with $80 \%$ electrification networks, drinking water and sanitation. The health and educational establishments are represented by 25 treatment rooms and 36 primary schools. The other school levels and the cultural, sports and commercial activities remain dependent with the chief places of communes.

\subsection{The Human Capacity Building and Technical Assistance program (HCBTAP)}

\subsubsection{Accompaniment of farmers and breeders}

The number of farmers who benefit from training and extension is still insufficient. It does not exceed $6 \%$ of the target for training, or an aggregate of 192 farmers, $44 \%$ in crop production and $56 \%$ in animal production. The planned extension number was $10 \%$, or 654 recipients, more than $50 \%$ of whom were interested in clarifying the agricultural and rural renewalpolicy. The training is provided by a local management at the two vocational training centers available in the area and based on arboriculture and beekeeping.

This poor result is justified by the large number of farmers in old age, illiterate and uninterested in agricultural technology, such as the limited experience of extension workers, the lack of means of travel and of collaboration between local authorities.

\subsubsection{The technical staff supervision}

A total of 8 local government officials (6 in the $R R$ and 2 in the AR) received upgrading training and refresher courses to ensure the smooth running of the program. The effectiveness of field project management is still insufficient due to the lack of necessary resources, inadequate administrative work methods and the institutional environment not adapted.

\section{Conclusion and recommendations}

The results of the ARRP in Ouarsenis remain below the expected economic objectives, a situation mainly expressed by the low income of the rural 
population and the persistence of a rural exodus to seek a second job. The level of state intervention remains low and most of the agricultural production has been self-financed $(63 \%$ of the total planted area). For the subsidy tools, IPPRD participates with the majority of the supported sectors: $89 \%$ for olive growing, 58\% for arboriculture, $60 \%$ for beekeeping and $6 \%$ for large livestock. The NFDAI is involved only in poultry farming by $29 \%$ of the sheds; some of the projects eligible for support have not been managed by the administration, mainly by means of irrigation to increase the irrigated area.

For the social component, El Ouarsenis has benefited from a lot of basic infrastructure (housing connected to the electrification and drinking water networks, roads, education, health etc.) that could contribute to improving the living conditions of the rural population. The situation will be favorable to the fixing and even the return of the population if efforts are consolidated on the creation of a dynamic of agricultural production based on beekeeping, poultry and olive growing and attract young people to join the trade of a farmer. To make this area a sustainable and attractive territory, it should be based on an integrated approach, bringing together the development of agriculture and economic diversification through rural trades such as the craft sector, sustainable exploitation of the forestry heritage and the development of ecological tourism especially around the axis of the cedar forest in AinAnter and the dam of Kodiet-rosfa.

At the global level, we consider that this policy of the ARRP launched in Algeria for the period (20092014) based on foundations that have not really translated on the ground in the continuity of previous approaches and a deficit of governance with material, financial and human resources poorly managed despite the richness of the approach traced for this strategy. We consider that the national program report presented by MARD on May 03, 2015, which gives a total agricultural growth rate of $8.33 \%$, remains in the form of the numerical results estimated from one region to another in the absence of an evaluation of reality on the ground.

However, the prospects for extending this policy exist and the recovery of the agricultural sector remains possible, but for the objectives to be realized on the ground, it will be important to:
- Set realistic targets according to the real potential of each region

- Jointly address the economic and social aspects through feasible projects

- Repair the administration responsible for the execution of the programs and to provide it with the appropriate means, defining the responsibility of each element responsible for the task awaiting it

- Restructuring the actors involved in rural development with a view to better organization of the sectors and the real involvement of farmers in their own projects

- Upgrading the technical skills of technicians responsible for program evaluation and training and raising farmers' awareness.

\section{References}

AKERKAR, A. Étude de la mise en œuvre du plan national de développement agricole et rural (PNDAR): cas de la wilaya de Bejaia: revue nouvelle économie, $\mathrm{n}^{\circ}: 12$ -vol 01, p. 15-29, 2015.

BEDRANI, S. L'agriculture, l'agroalimentaire, la pèche et le développement rural en Algérie. Options Méditerranéennes, Série B/nº 61, p. 36-73, 2008.

BESSAOUD, O. La révolution agraire en Algérie: continuité et rupture dans le processus de transformation agraire. Tiers-Monde, v. 21, n. 83, p. 605626, 1980.

BOUAMMAR, B. Le développement agricole dans les régions sahariennes;cas de la région de Ouargla et de Biskra. Doctoratethesis in economics, University of Ouargla, 2010, 296 P.

FERROUKHI, S. A. La politique du renouveau agricole et rural en Algérie,Une réponse au défis de la sécurité alimentaire, Paris, 17-19 décembre 2009 (seminar IPEMED-CIHEAM).

GCPH - General Census of Population and Habitat. Algeria, 2008.

HERSI, A. Les mutations des structures agraires en Algérie depuis 1962, 1981, $171 \mathrm{p}$.

MAGHNI, B. Analyse des politiques de soutienà l'agriculture en Algérie. Université de Béjaïa-Algérie, Presentation at Agro West Campus, les 12, 13 décembre 2013. 
MARD - Ministry of Agriculture and Rural Development. Le Renouveau Rural, un nouvel élan au monde rural s'impose par lerenouvellementFSP: L'ingénierie territoriale au service de l'attractivité, de la compétitivité et du développement durable des territoires, 2009.

Le renouveau agricole et rural en marche; Revue et perspectives, Mai 2012.

Bilan du programme de renouveau de l'économie agricole et rural (2009- 2014); 22e Session d'évaluation» 03 Mai 2015.

NCSAPD - National Center for Studies and Analysis for Population and Development. Problématique $d u$ Développement Rural, n. 51, nov. 2002.
SOUIDI, Z. and BESSAOUD, O. Valorisation des espaces ruraux en Algérie:une nouvelle stratégie participative. New Medit, n. 1, p. 17- 24, , 2011.

TEBANI, M. Etude d'impact environnemental et social du ProgrammeNational de Développement Agricole et Rural (PNDAR)et Perspectives dans un cadre de développement durable.Cas de la zone de l'Ouarsenis Wilaya de Tissemsilt (2000-2005). Memory of magister, university of mascara (Algeria), 2008, $214 \mathrm{P}$.

ZAGHIB, M. Evaluation et impacts des projets de proximité de développement rural (PPDR) sur l'agriculture et le développement rural local. Cas des zones de montagnes du Nord de la wilaya de Sétif. Memory of magister, University Ferhat Abbas de Sétif (Algeria), 2009.

Todo o conteúdo deste periódico, exceto onde estiver identificado, está licenciado sob uma Licença Creative Commons (cc by 4.0). 